\title{
Identification and Control of Coral Ardisia (Ardisia crenata): A Potentially Poisonous Plant. ${ }^{1}$
}

\author{
B. A. Sellers, Sarah Lancaster, K. A. Langeland, J.A. Ferrell, Michael Meisenberg, and J. Walter. ${ }^{2}$
}

Coral ardisia, also known as coral berry, spice berry, and scratchthroat, was introduced to Florida in the early 1900's for ornamental purposes (Figure 1). Since then, it has escaped cultivation, and it is found in hardwood hammocks and other moist, natural-wooded areas and grazing lands. Documented herbarium specimens, or preserved plants, have been collected from 19 western and south-central Florida counties (Wunderlin and Hansen, 2004). Coral ardisia is considered invasive by the Florida Exotic Pest Plant Council and the UF/IFAS Assessment (Fox et al., 2005).

\section{Identification}

Coral ardisia is an evergreen, sub-shrub that reaches heights of 1.5 to 6 feet. It tends to grow in multi-stemmed clumps. The alternate, waxy leaves are about 8 inches long, and they are dark green above. They are also hairless, with scalloped margins and calluses in the margin notches (Figure 2). Flowers are typically pink to white in stalked axillary clusters, usually drooping below the foliage (Figure 3 ). The fruit is bright red, globular, and one-seeded, measuring about 0.25 inches in diameter (Figure 4 ). Berries tend to persist on the plant nearly year-round, and white-berried populations also exist.

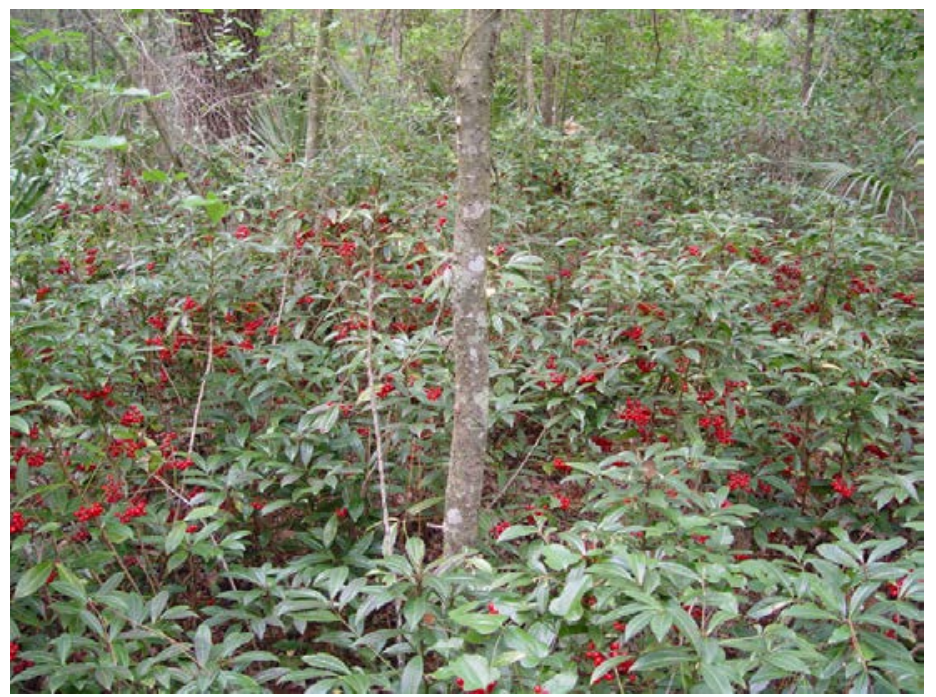

Figure 1. Coral ardisia in a hardwood hammock.

Credits: Michael Meisenburg

1. This document is SS AGR 276, one of a series of the Agronomy Department, UF/IFAS Extension. Original publication date September 2007. Revised November 2013. Visit the EDIS website at http://edis.ifas.ufl.edu.

2. B.A. Sellers, assistant professor, Range Cattle Research and Education Center-Ona, FL; Sarah Lancaster, Extension scientist, Range Cattle Research and Education Center-Ona, FL; K. A. Langeland, professor, Agronomy Department, J. A. Ferrell, associate professor, Agronomy Department; Michael J. Meisenburg, biologist, Center for Aquatic and Invasive Plants; J. Walter, Extension agent, Brevard County Extension Office; UF/IFAS Extension, Gainesville, FL 32611.

The use of trade names in this publication is solely for the purpose of providing specific information. UF/IFAS does not guarantee or warranty the products named, and references to them in this publication does not signify our approval to the exclusion of other products of suitable composition. All chemicals should be used in accordance with directions on the manufacturer's label.

The Institute of Food and Agricultural Sciences (IFAS) is an Equal Opportunity Institution authorized to provide research, educational information and other services only to individuals and institutions that function with non-discrimination with respect to race, creed, color, religion, age, disability, sex, sexual orientation, marital status, national origin, political opinions or affiliations. For more information on obtaining other UF/IFAS Extension publications, contact your county's UF/IFAS Extension office. 


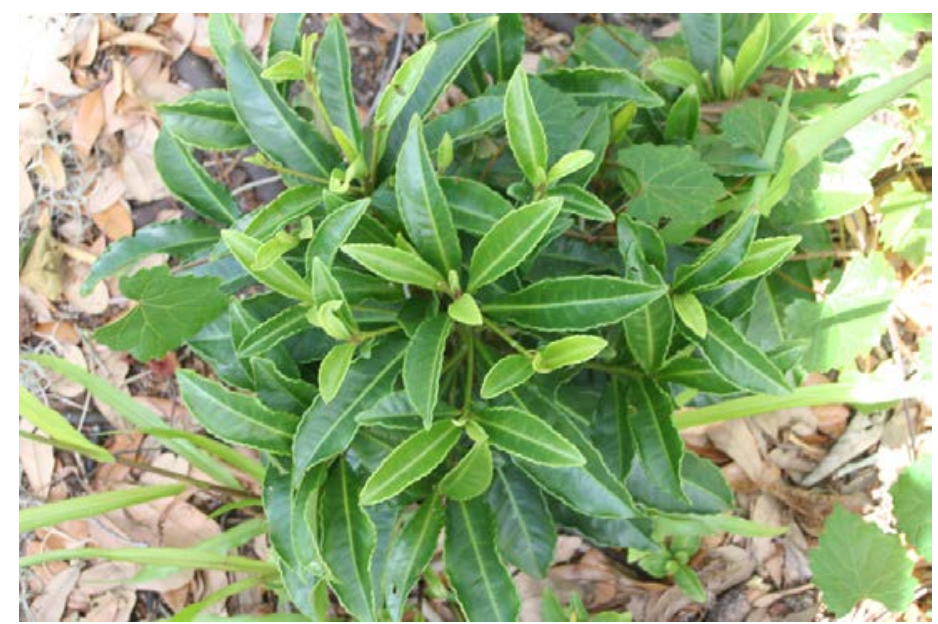

Figure 2. Coral ardisia leaves are waxy with a bright, shiny appearance. The leaves may contain substances that are toxic to cattle and other livestock.

Credits: Brent Sellers

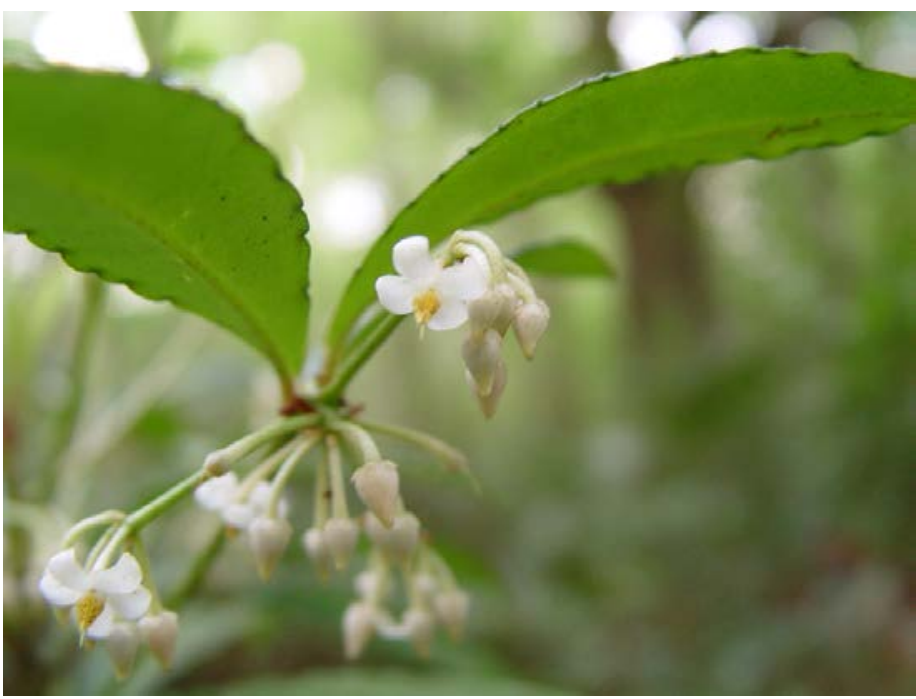

Figure 3. Coral ardisia has pink to white flowers in axillary stalks that tend to hang underneath the foliage.

Credits: Michael Meisenburg

\section{Toxicity}

Although there is no published literature supporting the theory that coral ardisia is toxic, it is suspected that the berries and/or foliage are poisonous to livestock, pets, and humans. In 2001, 2007, and 2012, the plant was the suspected causal agent for livestock deaths in Florida.

\section{Control}

Coral ardisia can be suppressed by using low-volume, foliar applications of $3 \% \mathrm{v} / \mathrm{v}$ (volume to volume) solution of triclopyr ester-containing products (Garlon 4 Ultra, Remedy Ultra, others), $4 \%$ triclopyr amine-containing products (Garlon 3A, others), or 1\% imazapic-containing products (Impose, Panoramic, Plateau) (Table 1). Basal bark applications with an $18 \% \mathrm{v} / \mathrm{v}$ solution of Garlon 4 or Remedy
Ultra in an oil carrier can also suppress the plant. Complete coverage is essential when using foliar application. Do not apply more than 8 quarts of Remedy or Garlon 4 per acre. If applying greater than 2 quarts, then treat no more than $10 \%$ of the total grazed area. Since formulations can evaporate when temperatures exceed $90^{\circ} \mathrm{F}$, use care when applying high rates of these herbicides. The herbicide Imazapic has been shown to reduce seedling germination within 12 months after application. Regardless of the application method, retreatment will be necessary for complete control. For more information on basal bark applications, visit http://edis.ifas.ufl.edu/AG245 to read the EDIS publication entitled "Herbicide Application Techniques for Woody Plant Control.”

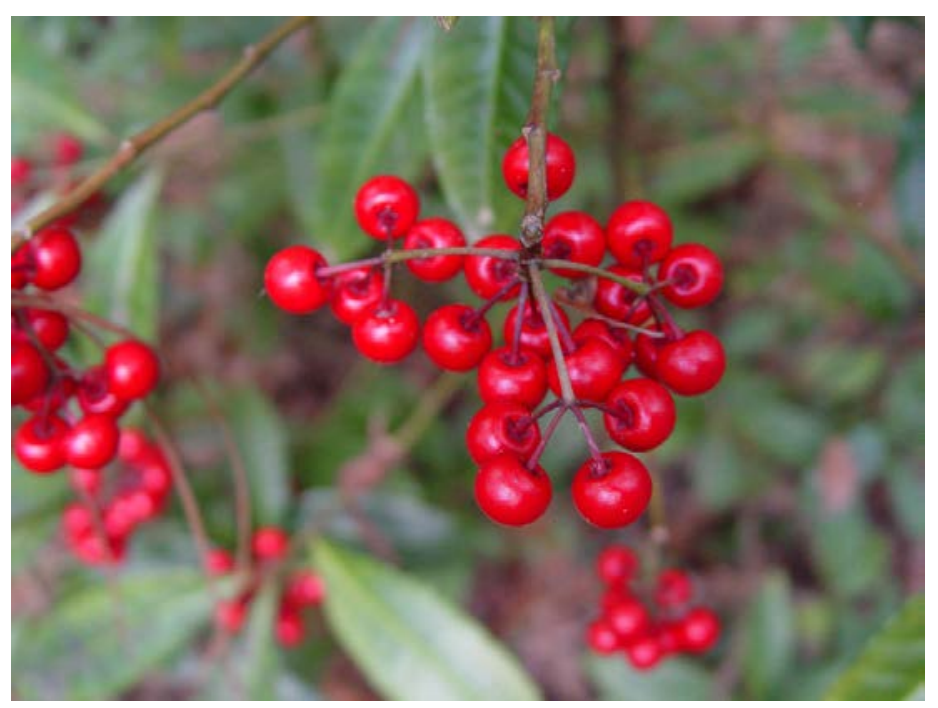

Figure 4. Coral ardisia has bright red berries. It is thought that livestock died after consuming the berries in 2001 and 2007 in Florida. Credits: Michael Meisenburg

\section{References and Further Reading}

FLEPPC. 2011. List of Invasive Plant Species. Florida Exotic Pest Plant Council. Internet: http://www.fleppc. org/list/1 1list.htm or Wildland Weeds Vol. 14(3-4):11-14. Summer/Fall 2011.

Fox, A. M., D. R. Gordon, J. A. Dusky, L. Tyson, and R. K. Stocker. 2005. IFAS Assessment of the Status of Non-native Plants in Florida's Natural Areas. Cited from the internet (September 25, 2013), http://plants.ifas.ufl.edu/assessment/ pdfs/status_assessment.pdf.

Hutchinson, J. T., K. A. Langeland, and M. Miesenberg. 2011. Field trials for herbicide control of coral ardisia (Ardisia crenata) in natural areas of north-central Florida. Invasive Plant Sci Mgmt. 4:234-238. 
IFAS Assessment. 2011. Conclusions from the IFAS Assess-

ment of Non-Native Plants in Florida's Natural Areas. http://

plants.ifas.ufl.edu/assessment/pdfs/concl_genus_Feb2011.

pdf. UF/IFAS Extension, Gainesville, FL.

Wunderlin, R. P., and B. F. Hansen. 2004. Atlas of Florida

Vascular Plants http://www.plantatlas.usf.edu/. [S. M.

Landry and K. N. Campbell (application development),

Florida for Community Design and Research.] Institute for

Systematic Botany, University of South Florida, Tampa, FL.

Table 1. Control of mature and seedling coral ardisia with selected herbicides 12 months after treatment. Adapted from Hutchinson et al. 2011.

\begin{tabular}{|l|l|c|c|c|}
\hline Active ingredient & Trade names & Rate (\% v/v) & Mature plant control (\%) & Seedling control (\%) \\
\hline Triclopyr ester & $\begin{array}{l}\text { Garlon 4 Ultra, Remedy } \\
\text { Ultra, others }\end{array}$ & 3 & 96 \\
\hline Triclopyr amine & Garlon 3A, others & 4 & 90 \\
\hline Imazapic & $\begin{array}{l}\text { Impose, Panoramic, } \\
\text { Plateau, others }\end{array}$ & 1 & 99 & 52 \\
\hline $\begin{array}{l}\text { Triclopyr amine + } \\
\text { imazapic }\end{array}$ & Garlon 3 A + Plateau & $4+1$ & 99 & 93 \\
\hline
\end{tabular}

